Analitika: Jurnal Magister Psikologi UMA, Vol. 11 (2) Desember (2019)

ISSN: 2085-6601 (Print), ISSN: 2502-4590 (Online)

DOI: http://dx.doi.org/analitika.v11i1.2957

ANALITIKA

Jurnal Magister Psikologi UMA

Available online http://ojs.uma.ac.id/index.php/analitika

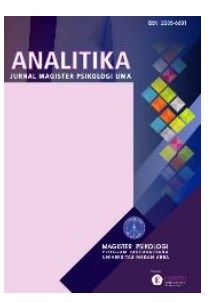

\title{
Efektivitas Pelatihan “Care Teacher, Fight Bullying” untuk Meningkatkan Keterampilan Pembinaan Anti-Bullying pada Guru Sekolah Dasar
}

\section{Effectiveness of "Care Teacher, Fight Bullying" Training to Increase Anti-Bullying Coaching Skills of Elementary School Teachers}

\author{
Zakiah Ulya* \\ Bidang Studi Psikologi Pendidikan, Program Studi Magister Psikologi Profesi, \\ Universitas Airlangga, Indonesia
}

Diterima: 6 Oktober 2019, disetujui: 28 Desember 2019, dipublish: 30 Desember 2019

*Corresponding author: E-mail: zakiah.ulya-2017@psikologi.unair.ac.id

\begin{abstract}
Abstrak
Penelitian ini bertujuan mengetahui efektivitas pelatihan "Care Teacher, Fight Bullying” untuk meningkatkan keterampilan melakukan pembinaan terhadap peristiwa bullying pada guru sekolah dasar. Penelitian ini menggunakan metode eksperimen kuasi dengan desain one gorup pretest-posttest. Sampel dalam penelitian ini terdiri dari 11 orang guru sekolah dasar di salah satu sekolah dasar di Kota Surabaya. Instrumen yang digunakan dalam penelitian ini terdiri dari tes pengetahuan bullying $(\alpha=0.71)$ dan pedoman observasi keterampilan pembinaan pelaku dan korban bullying (\%ARR $=0.89$ ). Analisis data yang digunakan dalam penelitian adalah uji beda non parametrik menggunakan teknik wilcoxon. Hasil penelitian menunjukkan bahwa terjadi peningkatan rerata skor keterampilan pembinaan anti-bullying yang signifikan sebelum $(M=6.82)$ dan sesudah $(M=16.45)$ diberikan pelatihan. Nilai perbedaan dapat dilihat berdasarkan nilai $\mathrm{z}=-2.953$ dan $\mathrm{p}$ value $<0.05$. Sehingga dapat disimpulkan bahwa pelatihan "Care Teacher, Fight Bullying" efektif untuk meningkatkan keterampilan melakukan pembinaan terhadap peristiwa bullying pada guru sekolah dasar.
\end{abstract}

Kata kunci: Pelatihan, pembinaan anti-bullying, guru sekolah dasar

\begin{abstract}
This study aims to determine the effectiveness of the "Care Teacher, Fight Bullying" training to improve the skills of coaching towards bullying incidents in elementary school teachers. This study uses a quasi-experimental method with a one-group pretest-posttest design. The sample in this study consisted of 11 elementary school teachers in an elementary school in the city of Surabaya. The instrument used in this study consisted of a bullying knowledge test $(\alpha=0.71)$ and an observation guideline for the coaching skills of the perpetrators and victims of bullying (\%ARR $=0.89)$. Analysis of the data used in this study was a non parametric difference test using the Wilcoxon test. The results showed that there was a significant increase in the mean score of anti-bullying coaching skills before $(M=6.82)$ and after $(M=16.45)$ training was given. The difference value can be seen based on the $z$ value $=-2,953$ and $p$ value $<0.05$. So it can be concluded that the "Care Teacher, Fight Bullying" training is effective to improve the skills of coaching the bullying incidents in elementary school teachers.
\end{abstract}

Keywords: Training, bullying coaching, elementary school teachers

How to Cite: Ulya, Zakiah. (2019), Efektivitas Pelatihan "Care Teacher, Fight Bullying" untuk Meningkatkan Keterampilan Pembinaan Anti-Bullying pada Guru Sekolah Dasar, Analitika: Jurnal Magister Psikologi UMA, 11 (2): 144 - 150 


\section{PENDAHULUAN}

Bullying di definisikan sebagai bentuk agresi yang mencerminkan adanya ketidakseimbangan kekuatan antara pelaku intimidasi dan korban (Pepler, Craig, O'Connell, Atlas, \& Charach, 2004). Terdapat berbagai bentuk perilaku bullying, ada yang terjadi secara langsung maupun tidak langsung, ada yang berbentuk bullying fisik dan verbal, bahkan ada pula perilaku bullying yang berbentuk cyberbullying.

Peristiwa bullying menghasilkan dampak yang destruktif pada individu yang terlibat di dalamnya. Secara nyata, peristiwa bullying akan berdampak pada siswa korban bullying yakni berupa cedera fisik, kepercayaan diri yang rendah, cemas, serta adanya perasaan takut bahkan depresi (Olweus, 1993). Smokowski dan Kopasz (2005) menyebutkan efek longitudinal yang mungkin dialami pelaku adalah termasuk potensi perilaku antisosial di masa dewasa, kinerja yang rendah, dan agresi terhadap anggota keluarga.

Fenomena bullying dapat terjadi pada berbagai tingkat pendidikan, termasuk pada anak usia sekolah dasar. Temuan pada penelitian yang dilakukan oleh Kustanti (2015) menunjukkan bahwa dari berbagai jenjang pendidikan di Kota Semarang, siswa di tingkat sekolah dasar adalah yang paling sering menerima perlakuan bullying yakni sebesar 82,98\%. Penelitian yang dilakukan oleh Siregar (2016) menggambarkan perilaku bullying pada anak usia sekolah dasar di Kota Medan. Hasil penelitian tersebut menunjukkan bahwa sebanyak 44,6\% anak melaporkan pernah melakukan bullying, dan sebanyak 22,2\% anak melakukan bullying dalam frekuensi 1-2 kali setiap bulannya.

Guru memegang peranan penting dalam pencegahan dan pemberian tindakan pada situasi bullying, baik yang terjadi di halaman sekolah maupun dalam ruang kelas, dimana siswa menghabiskan sebagian besar waktunya. Froschl, Sprung, MullinRindler, Stein, dan Gropper (1998) mengungkapkan bahwa guru berperan dalam memberikan intervensi pada peristiwa bullying, memberikan edukasi dan kegiatan mengenai bullying, membantu siswa dalam mengembangkan keterampilan sosial, mengatur rasa marah, empati, dan lain sebagainya. Selain itu, guru juga memiliki peran dalam menciptakan suasana belajar yang kondusif serta memberikan kesempatan bagi siswa untuk dapat bekerjasama.

Disamping pentingnya peran guru dalam melakukan pencegahan dan penanganan terhadap peristiwa bullying, terdapat beberapa penelitian yang menunjukkan bahwa guru dinilai kurang efektif dalam mencegah dan mengintervensi peristiwa bullying. Guru memiliki persepsi yang berbeda mengenai bullying sebagaimana yang dipersepsikan oleh siswa (Bradshaw, Sawyer, \& O’Brennan, 2007). Misalnya, guru tidak mempersepsikan bullying relasional sebagai suatu tindakan bullying dan kurang serius menanggapi peristiwa tersebut.

Berdasarkan

wawancara pendahuluan yang dilakukan oleh peneliti kepada guru-guru di salah satu sekolah dasar, diperoleh informasi bahwasannya guru-guru masih merasa bingung dalam membedakan antara peristiwa bullying 
dengan agresi non-bullying. Selain itu, guruguru juga lebih cenderung merasa penting untuk menindaklanjuti peristiwa bullying yang berbentuk fisik daripada jenis bullying lainnya. Hal ini dikarenakan persepsi guru bahwa peristiwa yang berdampak pada cedera fisik akan lebih berbahaya dibandingkan peristiwa bullying lain seperti bullying verbal atau relasional yang tidak berdampak secara fisik. Selain itu, guru mengungkapkan bahwa pembinaan antibullying yang dilakukan guru selama ini kurang efektif. Dimana siswa pelaku umumnya masih saja mengulangi perilaku bullying meskipun sudah dilakukan pembinaan.

Rowan (2007) melaporkan bahwa 14\% partisipan survei mengungkapkan bahwa guru cenderung mengabaikan kejadian bullying daripada berusaha untuk mengatasi kejadian bullying. Kurangnya intervensi dari guru akan berdampak buruk sebab pelaku atau korban bullying akan memandangnya sebagai bentuk persetujuan guru. Strohmeir dan Noam (2012) menyebutkan bahwa bullying mungkin akan berkurang apabila guru mengintervensi secara efektif segera ketika situasi terjadi, sehingga diperlukan keterampilan guru dalam melakukan pembinaan terhadap insiden bullying.

Kurangnya pengetahuan, kesadaran, dan keterampilan guru terkait bullying dapat menghambat upaya pencegahan dan penanganan bullying. Akhirnya akan mengarahkan pada pentingnya pelatihan kepada guru dan staf sekolah. Beberapa peneliti juga menyarankan bahwa guruguru hendaknya meningkatkan kapasitas mereka dalam mengidentifikasi bullying melalui partisipasi di dalam pelatihan (Oldenburg dkk, 2015). Pelatihan yang diberikan kepada tenaga kependidikan dapat meningkatkan pengetahuan mereka akan keterampilan penanganan bullying dan menggunakan keterampilan tersebut dalam menghadapi siswa untuk mencegah tindakan bullying (Duy, 2013).

Modul pelatihan dalam penelitian ini disusun oleh peneliti berdasarkan manual pelatihan Steps to Respect (Committee for Children, 2005). Materi dalam pelatihan anti-bullying dalam Steps to Respect tersebut terdiri dari materi utama yakni berupa konten mengenai bullying (definisi bullying, bentuk perilaku bullying, dan model untuk menanggapi laporan bullying). Materi tambahan yakni mengenai cara melatih siswa yang terlibat dalam bullying dan orientasi terhadap material kelas dan strategi instruksional dalam pencegahan dan penanganan bullying .

Penelitian ini selanjutnya bertujuan untuk menguji efektivitas dari pelatihan "Care Teacher, Fight Bullying" untuk meningkatkan pengetahuan dan keterampilan melakukan pembinaan terhadap peristiwa bullying pada guru sekolah dasar. Hipotesis dalam penelitian ini adalah pelatihan "Care Teacher, Fight Bullying" efektif untuk meningkatkan pengetahuan dan keterampilan melakukan pembinaan terhadap peristiwa bullying pada guru Sekolah Dasar. Manfaat dari penelitian ini secara teoretis yakni menambah informasi mengenai penerapan program intervensi dalam melibatkan guru untuk pencegahan dan penanganan bullying di sekolah. Manfaat praktis penelitian ini yaitu guru memperoleh 
pengetahuan dan keterampilan pembinaan yang tepat terhadap siswa yang menjadi korban maupun pelaku bullying.

\section{METODE PENELITIAN}

Variabel terikat dalam penelitian ini adalah keterampilan pembinaan antibullying, yakni keterampilan guru dalam melakukan pembinaan terhadap korban dan pelaku bullying sebagai tindakan intervensi terhadap peristiwa bullying. Sedangkan variabel bebas dalam penelitian ini adalah pelatihan "Care Teacher, Fight Bullying", yang mencakup materi mengenai dasar bullying, pencegahan bullying, dan penanganan bullying.

Subjek dalam penelitian ini terdiri dari sekelompok guru di salah satu sekolah dasar di Kota Surabaya. Subjek penelitian dipilih berdasarkan kesediaan untuk meluangkan waktu dalam kegiatan penelitian. Total guru yang mengikuti pelatihan adalah sebanyak 13 guru, namun yang mengikuti seluruh kegiatan hingga tuntas hanya 11 guru. Sehingga yang menjadi subjek dalam penelitian ini adalah 11 guru.

Penelitian ini merupakan penelitian eksperimen kuasi dengan desain one group pretest-posttest (Azwar, 2017). Pada desain penelitian ini, peneliti melakukan pengukuran terhadap subjek penelitian sebelum dan sesudah diberikan pelatihan.

Perlakuan yang diberikan dalam penelitian ini adalah pelatihan "Care Teacher, Fight Bullying", yang dibawakan oleh satu trainer dan satu co-trainer. Pelatihan ini diselenggarakan selama 2 hari dengan total waktu pelatihan 11 jam 15 menit. Pelatihan terbagi ke dalam 3 sesi yakni materi 1) Pengantar Bullying dan Mengenal Bullying Lebih Lanjut; 2) Bagaimana Merespon Bullying; dan 3) Pencegahan Bullying : Apa yang Seharusnya Dilakukan Guru?

Instrumen yang digunakan dalam penelitian ini terdiri dari tes pengetahuan bullying, panduan obervasi keterampilan pembinaan anti-bullying dan modul pelatihan "Care Teacher, Fight Bullying". Validitas tes pengetahuan bullying, panduan observasi, dan modul pelatihan sebelumnya telah diuji menggunakan validitas isi melalui professional judgement atau penilaian dari ahli. Tes pengetahuan bullying disusun dalam bentuk pilihan ganda dan terdiri dari 25 aitem dengan rentang skor 0 sampai dengan 1 . Skor 0 diberikan untuk pertanyaan yang dijawab salah dan skor 1 diberikan untuk pertanyaan yang dijawab benar. Adapun reliabilitas tes pengetahuan bullying adalah $\alpha=0.71$.

Panduan observasi keterampilan pembinaan anti-bullying terdiri dari 12 indikator keprilakuan dengan reliabilitas inter-observer sebesar 0.89 menggunakan percentage of agreement (\% $\mathrm{A}_{\mathrm{RR}}$ ), tergolong memuaskan (Sattler, 2002). Teknik pencatatan yang digunakan adalah rating scale dengan rentang penilaian 0 sampai dengan 2. Penilaian 0 diberikan apabila indikator observasi tidak muncul atau tidak dilakukan oleh partisipan, nilai 1 apabila indikator dilakukan namun kurang sesuai, dan nilai 2 diberikan apabila indikator observasi dilakukan dengan sesuai oleh partisipan.

Data dalam penelitian ini dianalisis menggunakan pendekatan statistik non- 
parametrik. Pendekatan non-parametrik dinilai sesuai dengan pertimbangan bahwa jumlah sampel penelitian yakni 11 subjek, kurang dari $30 \quad(\mathrm{~N}<30)$. Uji statistik menggunakan software IBM SPSS Statistics 24 dengan teknik statistik uji beda Wilcoxon.

\section{HASIL DAN PEMBAHASAN}

Pelatihan "Care Teacher, Fight Bullying" merupakan suatu program yang disusun dengan tujuan memberikan pemahaman kepada guru mengenai bullying, sehingga guru dapat membedakan antara perilaku bullying dengan perilaku agresi lainnya. Selain itu, program pelatihan ini juga membantu menumbuhkan kesadaran guru untuk secara konsisten menolak bentukbentuk bullying yang terjadi di lingkungan sekolah. Pelatihan ini juga memfasilitasi guru untuk dapat meningkatkan keterampilan dalam melakukan pencegahan dan penanganan terhadap peristiwa bullying.

Guru dalam pelatihan ini diberikan pengetahuan mengenai fitur-fitur penting dari bullying sehingga guru dapat mengidentifikasi peristiwa bullying di sekolah dan segera melakukan intervensi. Hal ini sebagaimana pendapat Chen, Sung, dan Cheng (2017) bahwa merupakan hal yang penting bagi guru memiliki kemampuan mengidentifikasi insiden bullying di sekolah, yang akan berdampak pada respon guru ketika dihadapkan pada insiden bullying. Apabila guru dapat mengidentifikasi bullying, maka guru juga akan dapat menentukan langkah intervensi selanjutnya terhadap peristiwa bullyuing tersebut.

Adapun fitur penting dari bullying yang disampaikan dalam pelatihan ini adalah 3 karakteristik bullying yang dikemukakan oleh Olweus (1993) yakni adanya niat untuk menyakiti, terjadi secara berulang, dan adanya ketidakseimbangan kekuatan. Pada saat pelatihan, trainer menyajikan kepada peserta beberapa uraian kasus bullying dan kasus non-bullying, peserta diminta untuk mengidentifikasi apakah kasus tersebut termasuk bullying atau tidak. Apabila kasus tersebut termasuk bullying, peserta diminta untuk menyebutkan 3 karakteristik utama dari bullying yang membedakannya dengan peristiwa non-bullying.

Berdasarkan uji hopotesis yang dilakukan pada tes pengetahuan bullying, terdapat perbedaan skor pengetahuan bullying sebelum $(\mathrm{M}=53.09)$ dan sesudah $(\mathrm{M}=85.45)$ diberikan pelatihan. Peningkatan skor pengetahuan bullying pada uji beda wilcoxon, ditunjukkan dengan nilai $\mathrm{Z}=-2.943$ dengan taraf signifikansi $0.003<0.05$. Artinya, pelatihan "Care Teacher, Fight Bullying" efektif untuk meningkatkan pengetahuan bullying pada guru sekolah dasar. Hasil penelitian ini sejalan dengan penelitian yang dilakukan oleh Chen, Sung, dan Cheng (2017) yang menyebutkan bahwa pelatihan yang diberikan kepada guru efektif untuk meningkatkan pengetahuan guru mengenai bullying terutama dalam mengidentifikasi bullying. Penelitian lainnya yang dilakukan oleh Saptandari dan Adiyanti (2013) juga menunjukkan bahwa pelatihan yang diberikan kepada guru efektif untuk meningkatkan pengetahuan guru mengenai bullying.

Tidak hanya sekedar pemahaman guru mengenai bullying saja yang perlu untuk ditingkatkan. Sebagaimana yang telah disebutkan bahwasannya penelitian 
ini bertujuan untuk meningkatkan keterampilan guru dalam melakukan pembinaan terhadap peristiwa bullying. Hasil uji wilcoxon pada keterampilan pembinaan anti-bullying menunjukkan bahwa terdapat perbedaan yang signifikan antara skor pretest dan skor posttest. Nilai perbedaan dilihat berdasarkan nilai $\mathrm{Z}=$ 2.953 dengan taraf signifikansi $0.003<$ 0.05. Hal ini berarti terdapat perbedaan yang signifikan pada rerata hasil pretest dan posttest, disertai dengan peningkatan pada skor posttest.

Hasil analisis statistik deskriptif menunjukkan bahwa rerata skor keterampilan pembinaan anti-bullying sesudah pelatihan lebih tinggi $(M=16.45)$ dibandingkan dengan rerata skor pembinaan anti-bullying sebelum diberikan pelatihan (M=6.82). Adapun Effect Size pelatihan "Care Teacher, Fight Bullying" adalah sebesar 0,629. Artinya besar pengaruh pelatihan "Care Teacher, Fight Bullying" adalah berada pada kategori sedang.

Program pelatihan ini juga mendorong guru untuk merancang suatu kegiatan atau aktivitas kelas untuk memberikan edukasi mengenai bullying pada siswa. Saat pelatihan, guru diminta untuk menentukan materi anti-bullying serta bagaimana materi tesebut disajikan kepada para siswa. Hal ini juga akan mendukung guru untuk dapat melakukan tindakan preventif terhadap peristiwa bullying (O'Moore \& Minton, 2004). Sebagaimana yang dijelaskan oleh Rigby (2007) bahwa sebagai upaya untuk mengurangi perilaku bullying terhadap siswa, perlu melibatkan siswa itu sendiri yakni dengan memberikan edukasi antibullying secara terprogram.

Secara umum, berdasarkan evaluasi terhadap kegiatan pelatihan, diketahui bahwa peserta pelatihan merasa puas terhadap pelatihan yang diselenggarakan selama 2 hari. Beberapa saran dari guru yang menjadi peserta pelatihan menyebutkan bahwa sebaiknya pelatihan diadakan pada hari libur dimana guru-guru secara penuh dapat meluangkan waktu. Hal ini berkaitan dengan 2 orang peserta pelatihan yang tidak dapat hadir dikarenakan sedang ada jam mengajar. Peserta mengungkapkan bahwa pelatihan anti-bullying yang diberikan sangat bermanfaat untuk meningkatkan pengetahuan dan keterampilan peserta pelatihan dalam penanganan bullying.

\section{SIMPULAN}

Berdasarkan hasil penelitian, dapat disimpulkan bahwa terjadi peningkatan pengetahuan dan keterampilan melakukan pembinaan terhadap peristiwa bullying pada guru sekolah dasar sebelum dan sesudah mendapatkan pelatihan "Care Teacher, Fight Bullying". Bagi pihak sekolah hendaknya dapat menerapkan pengetahuan dan keterampilan yang telah diperoleh selama pelatihan secara nyata sehingga dapat mendukung program sekolah anti-bullying. Hasil penelitian ini juga dapat memperkaya kajian mengenai program anti-bullying di sekolah dasar, bahwa pelatihan dapat dijadikan sarana untuk meningkatkan pengetahuan dan keterampilan penanganan bullying pada guru. Peneliti selanjutnya dapat memperluas materi pelatihan serta 
memperkaya analisis hasil penelitian dengan melakukan evaluasi perilaku dan evaluasi hasil terhadap pelatihan yang telah dilakukan.

\section{DAFTAR PUSTAKA}

Azwar, S. (2017). Metode penelitian psikologi (Edisi ke2). Yogyakarta: Pustakan Pelajar.

Bradshaw, C. P. Sawyer, A. L. \& O’Brennan, L. M. (2007). Bullying and peer victimization at school: Perceptual differences between students and school staff. School Psychology Review. 36 (3): 361-382.

Chen, L., Sung, Y. \& Cheng, W. (2017). How to enhance teachers' bullying identification: A comparison among providing a training program, a written definition, and a definition with a checklist of bullying characteristics. The Asia-Pacific Education Researcher. 26 (6): 351-359.

Committee for Children.. (2005). Steps to respect program guide: Review research. Diunduh di www.cfchildren.org tanggal 12 April 2019.

Duy, B. (2013). Teachers' attitudes toward different types of bullying and victimization in turkey. Psychology in the schools. 50(10): 987-1002.

Froschl, M. Sprung, B. Mullin-Rindler, N. Stein, N. \& Gropper, N. (1998). Quit it! A Teacher's Guide in Teasing and Bullying for Use with Students in Grades $\mathrm{K}-3$. Washington DC: NEA Professional Library.

Kustanti, E. R. (2015). Gambaran bullying pada pelajar di kota semarang. Jurnal Psikologi Undip. 14(1): 29-39

O'Moore, M. \& Minton, S. J. (2004). Dealing with bullyng in schools. New Delhi: Paul Chapman Publishing.

Olweus, D. (1993). Bullying at School: What we know and what we can do. Oxford: Blackwell.

Oldenburg, B. Van Duijn, M. Sentse, M., Huitsing, G. van de Ploeg, R. Salmivali, C. \& Veenstra, R. (2014). Teacher characteristics and peer victimization in elementary schools: A classroom-level perspective. Journal of Abnormal Child Psychology. 43(1): 33-44.

Pepler, D. Craig, W. O'Connell, P. Atlas, R. \& Charach, A. (2004). Making a difference in bullying: Evaluation of a systemic school-based programme in canada. Dalam Smith, P. K.,
Pepler, D., Rigby, K. Editor. Bullying in schools: How successful can interventions be. Cambridge: Cambridge University Press.

Rigby, K. (2007). Bullying in schools and what to do about it. Victoria: ACER Press.

Rowan, L. O. (2007). Making classroom bully-free zones: Practical suggsestions for educators, Kappa Delta Pi Record, 43 (4), 182-183.

Saptandari, E. W. \& Adiyanti, M. G. (2013). Mengurangi bullying melalui program pelatihan "guru peduli". Jurnal Psikologi. 40(2): 193-210.

Sattler, J.M. (2002). Assessment of children: Behavioral and clinical application (5th ed.). La Mesa, CA: Jerome M. Sattler, Publisher.

Siregar, J. (2016). Gambaran perilaku bullying pada masa kanak-kanak akhir di kota medan. An-Nafs. 10(1): 1-11.

Smokowski, P. R. \& Kopasz, K. H. (2005). Bullying in school: An overview of types, effects, family characteristics, and interention strategies. Children $\mathcal{E}$ Schools. 27(2): 101110.

Strohmeier, D. \& Noam, G. G. (2012). Bullying in schools: what is the problem, and how can educators solve it?. New Directions for Youth Development. 2012(133): 7-13 